Copyright (c) 2006 Associação Brasileira de Pesquisadores em Jornalismo / SBP Jor

\section{CTBERJOURNALISM AND THE SCIENTIFIC BASES OF NEWSWRITING}

\author{
CONCEPCION EDO
}

Universidad Complutense de Madrid, Spain
ABSTRACT

KEY-WORDS
The situation regarding information that we are presently experiencing foretells an important transformation in Journalism. But since in order to transmit rigorous informative contents, to interpret reality, we are not able to work without preparing informative texts as a basic element of Newswriting, it is important to determine their role in this electronic writing phase. Evidently the need exists to always make them briefer, more documented and more attractive. Journalistic Newswriting or Cyber-Journalism occupies a primary place in the preparation of future professionals in the media and in Journalism teaching.

Journalism, cyber-journalism, electronic writing, journalistic newswriting.

In these first years of the XXI century, the influence of new communication media - the cyber-media - is already evident to all in society, as well as the changes that digital technologies have produced in journalism and in the work of journalists. There is reason to believe that the informative situation that we are presently experiencing will lead us to an important transformation of journalism that may alter both the importance and the development of the profession as well as its ethical aspects and quality

All these matters are of major importance and would deserve later studies, but there is yet another which is worthwhile mentioning and on which this work shall be focused: the role of written journalism, of the text, together with supports such as the fixed or moving image, sound and the possibilities of infography in an interactive space in which the hypertext suggests new methods of information. 
We are already irreversibly immersed in what Piscitelli calls the "electronic phase of writing". And now, as before, in order to transmit rigorous informative contents that interpret reality, neither in newspapers nor magazines, nor in radio or television informative programs, nor much less in the constant updating of news in digital media is one able to work without preparing informative texts. Whether long or brief, with large captions or in a small space, with images and sound or just as it is produced on the keyboard, text is the basic element in the task of informing that can never be ignored when compiling the news.

If we observe different research works undertaken during the last decade on the process that readers follow when they are informed on the Internet, we can conclude that news texts - especially captions and summaries - are the first items that readers notice in order to acquire journalistic information. And only after previously consulting the selected article on the home page do they proceed to photographs, graphs or the moving image.

The text captures attention, while in printed newspapers and magazines the images are what attract the reader.

Among others, there are three studies undertaken in the United States that concern identification of tendencies in the manner of reading the press. The first is dated 1990 and on that occasion the Poynter Institute analyzed the method of reading the printed press. The investigation concluded that the iconic elements - particularly photographs - were what first interested the readers.

The second one was focused on digital media with the participation of Stanford University and the Poynter Institute, and was made public during the first days of May, 2000. Researchers then used special micro-cameras that were adapted to the head and software that recorded ocular movements, the time of fixation on different points of the screen, mouse clicks and navigating from page to page. One of the conclusions they reached was that short articles are read three times more than long ones, but people go more deeply into the reading of subjects that interest them most.

In the third one dated 2004, the Poynter Institute also participated with the Estlow Center for Journalism \& New Media and Eyetools and, although it was not an exhaustive analysis, it presented interesting conclusions. Among others, that when entering the page, the eyes first read what appears on the upper left part of the screen, that captions immediately attracted attention and that photographs were not the first to be seen. And also that smaller-size letters lead to reading, while larger ones made the web visitor limit himself to scanning. Definitely, the Internet is firmly based on text in spite of all its multimedia possibilities. 
For this reason, it is convenient to point out that printed letters will not disappear in cyberspace, although their support may change, and also that, at least for several more years, the printed text that tends to become the appropriate framework for plural analysis and contrasted opinion will not succumb to the informative wave offered - and which will be offered even more - by both national and international portals, sites of any type present on the network, blogs, television chains, radio stations, newspapers and magazines. And it is possible that the major social danger from the perspective of journalism will be that citizens will become "information sick" (GITIN, 2005), saturated by data, images and sounds that they are not capable of assimilating and never satiated with so much information that is mainly ephemeral.

But in order to access all this and above all, to be able to understand this, it is indispensable to read the written messages that, for better or worse, explain all this communicational tangle. Journalism cannot put aside the compiling of texts, although the need to make them briefer, more documented and more attractive is evident. Therefore, Journalistic Newswriting or CyberJournalism has a primary place in the preparation of future professionals and in the teaching of journalism, regardless of the name of the subject studied at each university. But what must be taken into consideration is that another type of flat surface that is similar to paper may be used - with the prospect of a very thin screen - of which there are prototypes already with possibilities for large-scale production.

\section{1 - JOURNALISTIC TEXTS}

Together with the public's interest to be informed is the need to transmit information, the irrevocable fact that there is no news if there is nobody to edit it. And newswriting is putting into writing those things that happen, are agreed on or thought about previously (REAL ACADEMIA ESPAÑOLA, 1992, "Redactar"), or putting into writing facts or ideas in an orderly manner (SOUSA, 1992; ZUAZO, 1976). Regarding the editor, he is the person that edits or forms part of a newswriting office where editions are prepared (REAL ACADEMIA ESPAÑOLA, op.cit, "Redactar").

But Journalistic Newswriting - that is materialized through certain texts that narrate and analyze new or current events that make up the present state of things - is not restricted to such a reduced role. It is a university subject that is located in the social sciences and has all the typical elements of the phenomena of communication: the exchanging of information between a sender and a receiver, a message, a code to 
interpret it, certain means to transmit it.

If we look for a definition for this concept, we may say that it is (ALBERTOS, 1991: 21 and foll.) the science that concerns the study of specific signs - natural and technical - arranged in a unit of thought with the purpose of transmitting data and ideas of general interest by means of a newspaper or any other means of mass communication. And in this manner it deals with the way to obtain a certain degree of communication between persons of a specific human group by means of the correct and honest use of concrete techniques of expression.

Other authors (CASASÚS, 1988: II) define Journalistic Newswriting as the study of selection and evaluation procedures for facts and ideas, and of the forms of expression and internal and external structures adopted by informative present-day messages and journalistic Newswriting units in general, when being channeled through the printed press and other mass communication media. Or they focus on an aspect that has more specific variations: Journalistic Newswriting is not a mere act of newswriting but the act of informing or newswriting in order to inform (LADEVEZE, 1979: 78), and besides, it has an active dimension and social consequences that cannot be ignored because they are a part of its contents and are integrated into its function.

But what exactly is Journalistic Newswriting? Is it a science or is it only a technique? And, as we shall see further on, if it is truly a science, where and how must it be classified? The answer is that we find ourselves facing a science that is eminently social but that has important connections with the group of human sciences.

If we only take into account the proposed definitions, we may consider that the specific work of an editor in a communication media, both printed as well as audiovisual or digital, is simply to edit news. But in reality the journalistic task that is visible in texts that are published or read in different forms of the press includes many phenomena and activities of a varied nature that are adjusted to its journalistic variety. And the Spanish doctrine on Journalistic Newswriting that follows in the path of the theoretical positions of great American and European authors who are specialists in this matter openly underlines the existence of this wider scope (CASASÚS, op cit: 11-12).

The editor of a media newspaper not only writes but, in a communication context such as that of the present day - in which normally an excess of data and an amount of information are produced that overflow the space and the media - he must be capable of selecting texts, organizing the total or partial contents of the newspaper, order 
by hierarchy the informative and interpretative spaces and, definitely, to focus his attention on evaluating the news, and the strictly editorial function may be considered secondary in the daily routine of informing.

Therefore, it is not strange that from the very beginning of the educational history of Journalistic Newswriting this subject has been explained to students by taking into consideration two different but complementary and inseparable objectives: to teach them to evaluate and rework the informative texts that have already been written, and to teach them to write by themselves. However, for this aspect to have the efficacy required for the training of future journalists, it is necessary for them to have a sufficiently complete knowledge of their own language so as to be able to write what they know in a correct and personalized fashion. And if this previous knowledge does not exist, it is very difficult for students to assimilate the theoretical and practical bases of Journalistic Newswriting. In any case, it is advisable that study plans include - as on the other hand has occurred until now - a subject that reinforces the students' previous linguistic knowledge.

All these educational criteria correspond to the different functions of the informer in a newsroom such as well-known masters of journalism have stated in their time (DOVIFAT, 1960), summarizing them in three functions: to put together, to classify and to give shape to the news. Or, translated into the language of newsrooms of print and digital newspapers and of informative audiovisuals, the work of the reporter, of the compiler and of the editor.

From what we can consider as being a general initial outlook of the work in each one of the different communication media, the reporter is usually centered on looking for, selecting and preparing the news; the compiler orders it and above all, selects those items which he believes have a true interest for the reader ${ }^{1}$ - it is precisely in that setting where the proposal of one of the authors quoted can be integrated to define the journalistic action of Newswriting as the fact of knowing how to find space for what is essential (AGNER \& CROISSANDEU. Lire le journal, in ISI, 202) - and finally, the editor seeks the possible meanings of the events and systematizes the information that he has obtained by giving it a form or one or several distinct opinions.

However, it is necessary to recall that informative practice is not always so clearly outlined and very frequently a major variation in the normal distribution of the tasks occurs in order to complete the informative contents within the specific period - instantly, timely, daily, or weekly - in which each media informs its audience. Another matter 
worth mentioning here is the decisive importance that the appropriate and complete training of the informer has - now, maybe, more than in any other stage of the history of journalism.

As has been stated previously, it is not enough to have a certain intuition to capture what is news and linguistic knowledge to narrate it, but it is necessary to acquire a truly professional capability for observation and analysis, to have sufficient knowledge concerning the subject which is normally being written or considered, and to know the best method of reaching the appropriate sources that provide trustworthy information.

The work of the journalist - inevitably marked by urgency and always lacking the desirable time to reconsider the data and to reflect on its consequences - must rely, in spite of everything, on the effort required by the verification of what he has seen, heard or read. Consulting those sources, possibly less accessible or more difficult and opaque, that offer the true facts that confirm first impressions, must be carried out. And he must always be intent on verifying the facts with scientific research methods that make it possible to prove the hypothesis, more or less adventurous, and that serve to offer readers reality and not suppositions that do not provide a sufficient guarantee of credibility.

One of the keys to having texts published that conform to this method and verifying, in each case, the accuracy of the contents is doubtlessly the specialization of the journalist that interprets the contents and sources of the subject or subjects on which he focuses with greater efficiency. His self-assurance grows when he is an expert in a specific matter, and his greater accessibility to sources and specific points of the subject, the solidity of his training and his work methods, and the opportunity for ascent that this means in his own professional career, all this makes him feel, and in fact he shall be, more authorized to personalize the information that he signs (DIEZHANDINO, 1994: 32).

Different authors have already mentioned the present loss of relevancy of the ordinary journalist in a society in which new techniques mark the rhythm of communication media. And they also assure that, in spite of the weight given the deadline set for closing the edition in some cases and the immediacy that the Internet imposes in others, in spite of the difficulties involving sources and the still insufficient number of professionals who know how to write well, attractively and directly, the reporter in those moments must be fast as well as lucid, wise, a good investigator, an authority on his subjects and capable of detecting the true interests of the persons that form the audience at that specific moment (DENNIS \& ISMACH, 1981:21). He must also adhere to well- 
defined points of reference that have been expressed in this paper and that may be summarized in the following four items:

- Not to rely on data from a single source to prove or contradict information obtained;

- To normally take care in the correction and exactness of language in which imagination and the readers' capability for understanding must not be lacking;

- To write about what he knows, primarily thinking of the interests and needs of his readers;

- And finally, to have a deep knowledge of one or various subjects that form the informative structure of the media.

But in order to classify the scientific quality of this study area whose contents we have just explained in a true manner, it is indispensable to define with the greatest exactness the methodological area in which Journalistic Newswriting is included in the context of Communication Sciences, and to determine what Journalism represents as a social phenomenon and as a communication technique between individuals and groups (ALBERTOS, 1991, 22).

\section{COMMUNICATION SCIENCES}

Concerning Communication Sciences, we can start with a series of studies undertaken during the first half of the XX century which conceived the existence of three semiological levels - semantic dimension, syntactic dimension and pragmatic dimension -that have been reference points for later studies on human communication ${ }^{2}$. One of them that coincided chronologically with the initiation of Spanish university studies in journalistic communication established a practical adaptation of that initial outline ${ }^{3}$.

As we have seen, this outline divides the possibilities for human communication into three different parts that are well-defined: a syntactic one that basically directs its studies toward problems that appear in the transmission of information; a semantic one that concerns meanings and codes; and finally a pragmatic one whose objective is to communicate from a perspective that affects conduct (COSTA, 1972: 145 and fol.).

Of all these parts, it is particularly the third and last one that proposes an appropriate outlook for the subject of this study, although in that work scheme two aspects that are now indispensable for understanding communication phenomena are not yet contemplated: its mass dimension and the influence of technological advances. Thus, the point of intersection 
of Journalistic Newswriting with studies on human communication (...) must be located at the pragmatic level or area in accordance with the division by Morris, that is, at the level that concerns communication as a social fact that affects human beings.

In reality, both from a theoretical perspective as well as from a more utilitarian outlook, if the plan of studies is well-structured, all the subjects that are given in the Faculties of Information Sciences are concrete aspects and indications of Human Communication Sciences contemplated from the pragmatic and synthesizing point of view: how messages channeled through modern collective diffusion techniques can influence people (ALBERTOS, op cit: 25) because any message seeks, to a larger or smaller degree, to directly influence the conduct of the people who receive it, and in that aspect, the different communication media, whether printed or audiovisual, are no exception ${ }^{4}$.

The message that is disseminated by mass media then has a particular aspect that strengthens its relevance and is usually expressed in the weight of the influence it has on the receptors - all human communication presupposes a certain degree of intention - and as most communication sociologists admit, it also shows the frequency with which a favorable or contrary attitude is generated with regard to its contents.

There is then a political repercussion in journalism and, in a society such as the present one, it can be stated that a fundamental element for the democratic solidity of a country is to be able to carry out the necessary control of the different public communication media in favor of all citizens.

Therefore, if we start from the fact that Journalistic Newswriting presupposes the ordering of signs in a unit of thought to transmit data and ideas of general interest through a mass communication media, and that it is also a model for establishing relations of communication between specific human groups, one may conclude that it concerns a branch of Communication Science on the pragmatic level that has been considered in the previous paragraphs. And this is so to the extent that one of the areas into which these Communication Sciences are divided has as its purpose the study of human behavior and of the causes that influence people's conduct.

Thus, from this perspective, we see that the study of Communication such as it is understood in its philosophical aspect is included in this category, and that it must be directly related with a Theory of Knowledge. However, we can also see that it has points in common with what has 
been expressed by Political Theory as joint action - the co-action - of people concerning world matters (CASANOVA, 1968: 16).

Even more precisely, Journalistic Newswriting as a method for establishing relationships between human groups is a social phenomenon that is different from others because of two of its characteristics:

- it is a concrete form of mass communication, and besides

- it refers to singular contents: the transmission of facts, ideas, concepts and judgments.

These peculiarities verified in the subject that we are studying in this work lead us to consider this specific model of communications as being knowledgeable and reflective ${ }^{5}$. But although it is true that Journalistic Newswriting is included in what we have previously called in these pages the pragmatic area of the communicative discourse, it is not possible to separate it from the different semantic aspects it offers - that of grammar and linguistics - to begin the study of certain common codes that provide understanding within the social environment in which the transmission of the informative text takes place.

\section{INFORMATION AND JOURNALISM}

Information is a social phenomenon that, as a synonym of news or message, is linked to the contents of something signified to an individual receptor and, in a more precise sense, expresses the amount of information transmitted by that message (MOLES, 1975:374). And it is based on two propositions: a peculiar relationship between the issuer/informer and the receptor, and a particular work technique (FATTORELLO, 1964:15-17) by means of actions with specific results regarding the reactions of persons who participate in the informative process (ALBERTOS, 1991:36).

In this aspect we can refer to two different types of information (FATTORELLO, op cit: 41-42): a contingent one limited by time and reflecting actuality that includes both journalism as well as publicity, propaganda and public relations; and another non-contingent one that provides a certain degree of true communicational relation which includes all the varieties of human communication that are materialized through personal contacts. They are two models that use different forms with the same elements and the same structure.

But in spite of these theoretical details, in reality when we speak of information, we are usually referring to contingent information, the first model. And we would have to add to this that, since the last years of the 90s, the border line separating these two informative methods 
has been disappearing as a consequence in good measure of interactive phenomena that are produced by the application of new technologies of information transmission to communication media.

Presently, digital publications issued through the network already afford a more direct relationship between the issuer and the receptor - this has still not been developed very much in Spain in the early XXI century, but it has evident possibilities for growth in the near future whereby readers talk with, chat ${ }^{6}$ with, write to the journalist who signs the text, the director of the publication and on many occasions, the actors of the events.

What initially would be contingent information produces a closer relationship than the non-contingent or communicative type, because these media are not limited to issuing messages - in this case news with its corresponding interpretation and opinions - but rather make possible a certain degree of personal relationship with any of the issuers of information and even with the sources. And it is foreseeable that this relationship will become easier with the generalization of interactive television.

Returning to the observations of the authors that initiated this discussion, we must say that contingent information has several varieties but it maintains a common objective in all of them, which is to try to promote specific judgments or attitudes on the part of the citizens of a community, the polarization of individual opinions concerning something that is more or less debatable: public opinion (ALBERTOS, 1991:39-40).

It also has certain common characteristics that are useful for defining what makes up its entire purpose and objective - novelty, publicity, timeliness and generic nature for some of the experts in this matter, and actuality, periodicity and diffusion for others ${ }^{7}$ - to which we must add, when we refer to journalism, periodicity ${ }^{8}$.

The varieties of contingent information that are now expressed in the same order in which they have been previously quoted in this text, are four. In each case they correspond to types of professional activities that are very different from each other, and although in all of them there is a transmission of data, a receptor and an issuer, the purpose is completely different. We refer to Journalism ${ }^{9}$, Publicity ${ }^{10}$, Propaganda ${ }^{11}$ and Public Relations ${ }^{12}$.

Of all these we shall comment on the first, journalism, which is presented with a specific purpose different from the other three. This purpose consists of disseminating in a manner that is sufficiently objective 
those events or ideas of general interest that at a particular moment are considered as being news.

Together with this we must say that what we call present-day information or Journalism also has a series of peculiarities that mark the visible differences in the contents of the message and determine whether an event is or is not journalistic, and that are summarized in the following four points:

- Its purposes are informative,

- It is based on a concrete, precise theory of news,

- It takes for granted a certain psychological disposition on the part of journalists - who are issuers - regarding objectivity, or rather, regarding intellectual honesty, and

- This intellectual honesty is reflected in the respect for the freedom of response by the receptors.

\section{THE SCIENTIFIC CHARACTERISTIC OF JOURNALISTIC NEWSWRITING}

To complete these notes on Journalistic Newswriting, we must begin by determining whether or not it concerns true scientific knowledge or whether, as in some opinions that present journalism in an outdated, partial or biased manner, it is a form of artistic-literary creation or a technique that is acquired through a more or less brief period in the Newswriting offices of newspapers, magazines, digital media, radio or television chains.

In the first place, scientific knowledge is differentiated from ordinary knowledge because it is common and objective, although it may be exclusive for a specific intellectual level and requires a specialized application. In the second place, it is critical knowledge that is obtained through a logical method in order to avoid error. It is not only a method but it is also total: This science is total precisely because it seeks the principal general orders that may be assembled in an order of general universal principles, so that each group of specialists contributes, with their particular effort, to a more perfect knowledge of the totality of what is knowledgeable (D'ORS, 1969).

In the case of Journalistic Newswriting, we are facing a subject - an eminently social science, as has been stated, with important connections to the group of human sciences - that shows all these characteristics in its totality. Other authors added, more specifically, that social processes have been centered on the theoretical nucleus of communication, the different 
social process of the public transmission of messages, more emphasized in channels and methods of diffusion than in communicated content itself, and in attempts to reach a degree of global concentration that would simultaneously account for all of them, by and for themselves, in their interaction and in relation to the macro-social context in which they were inserted. This intention and its modest success focalized separately and in the proper perspective of each specific mass communication media, is what is known as Communication Sciences (BENEYTO, 1972:14).

Thus, we are dealing with a subject that is truly scientific and it is necessary to insist on the need to reject any other opinion regarding this matter that would attempt to explain it as a means of artistic creation or a pure and simple technology, because it concerns true scientific knowledge that studies messages not only as individual creations but as social visions (D'ORS, 1969: 10-11), and that notes, above all, the complete and total meaning of its repercussion on society.

Therefore, to the definition that has initially been given to this matter ${ }^{13}$, that adjusts and expresses what in reality is the concept of Journalistic Newswriting such as we understand it today, we would have to add that this science, understood as a form of communication that is included in the group of social sciences, involves the study of literary and visual messages that certain social groups channel to human masses (which we shall call the public) through mass media and with the purpose of providing current information (ALBERTOS, op cit: 76).

Besides, there is a clear difference between the focus of Journalistic Newswriting and the Spanish Language that is stated in the study plans of all Spanish universities that offer these studies, and that also appears in studies in other countries.

On the other hand, if it has been made clear that this subject has as its purpose the study of the informative message destined to a specific public, it is convenient to specify what exactly this type of message is that is normally expressed by means of a text.

In the first place, it may be analyzed from a humanistic perspective taking into consideration aesthetic or philosophical aspects but, in a broader concept, it can also be considered as a means to understand the behavior of journalists, the social and economic rules that govern newspapers, the variables that influence the presentation of the quoted messages, their influence on the receptors or the social rules of interaction between communicators and the public. It is this second aspect that corresponds to a specific intellectual attitude by the scientist, the one that originates the comprehension of Journalistic Newswriting as a social science different from the exclusively linguistic focus. 
In this manner Journalistic Newswriting contemplates the informative message as a peculiar system of signs placed in order according to precise syntactic rules. These syntactic rules present the conditions for ordering the signs that make up the particular code of the informative language; in other words, they constitute the group of communicative conventions that regulate the use and organization of a specific number of meanings (ECO, 1969:131).

Concerning their purposes, from an exclusively academic point of view they may be summarized into three main points (DIEZHANDINO, 1994: 21-22):

- They concern training the student from the humanistic and professional point of view by offering the fundamentals of the communication process;

- They emphasize the practical aspect of these teachings with the resulting capability to seek, select, prepare and edit the information, and

- They prepare the future professional for analysis of the information message.

Perhaps we may add to all this that in order to prepare journalistic texts that are truly profitable, it is necessary to have the capability for synthesis - even more essential for the information professional in the communication media whose work begins by selecting what is truly a piece of news from among excessive data - a normal desire to organize and plan the work, and the professional ability to be understood and to present the facts and their meaning in a manner accessible for the receivers.

To arrive at those definitive pages that are to be published, there is an entire work procedure to be followed, more or less long in each case, in which the journalist must know how to detect in a timely way - with active and participating observation - the specific event that is news at the moment and highlight it among many others which have been available to him.

He needs to seek and utilize the most trustworthy sources; he must commit himself to preparing true and complete information; he has to place his intellectual, professional and human status at risk and he needs to have basic training in Social Science research methods ${ }^{14}$. Only in this manner can he give vigor, credibility and consistency to the reality he narrates every day, and efficiently inform without superficially twisting the facts due to a lack of or inadequate training (DIEZHANDINO, op cit: 22-23). 
Studies also exist which, when referring to these requirements for the informer - who is not simply an aseptic transmitter of what he sees, hears or knows - assure that they can be reduced to two aspects that are clearly differentiated: the ability to reach the public, regardless of the specific contents of the message he transmits; and the capability for deciding what must be informed through communication media, because he is an expert who informs, evaluates and argues at the service of the reader and not only an editor who writes (LADEVEZE, op cit: 77 and fol), with no further aspirations other than offering the public his written or verbal presentation.

In summary, we may say that this involves undertaking a professional activity that on many occasions is specialized and intermediary - in certain circumstances the informer also becomes an active subject -, but without forgetting that journalists are specialized in their profession not only as simple informative intermediaries, but as intermediaries between the different practices of the written and spoken language that seek, in any event, to be understood by those who will read their texts or listen directly to their words (LADEVEZE, 1991: 25 and fol.).

On the other hand, Journalistic Newswriting offers several subdivisions that have been gradually incorporated into the bibliography on this matter and that broaden the scope of its scientific and academic perspectives (CASASÚS, op cit: 51 ): the theory of events ("Ephemerology"); the Journalistic perspective that includes the study and practice of different journalistic genres, the history of journalistic literature and specialized journalism; the theory of the newspaper ("Hemerology"), and finally, the analysis of the media and present-day messages ("Hemerography").

But all these aspects and others that are derived from the ones described here may be analyzed - we must insist on this point - using scientific methods that are characteristic of social sciences and also, more specifically, of Philology. This combination leads to a new and particular methodological system, with its specific work procedures that lead us to state that this academic subject is an autonomous science and presently completely independent from its socio-philosophical and humanistic origin.

Finally, we must refer to the scientific objective of Journalistic Newswriting that, from a general point of view, is the study of the present informative message in all the methods in which it may be presented. In addition, it studies the form adopted by this message on different occasions when channeled through the various printed or audiovisual 
media. This scientific objective may be the subject of research from different points of view, on the other hand, which are all interrelated.

In the first place, a general view of the mass communication media must be presented as well as the technological possibilities to be studied. Secondly, we must refer to the presentation of Journalism or PresentDay Information. Thirdly, we mention the need to establish a theory of news and then of the media environment. Finally, we must study the informative message in itself, analyzing the texts as well as the titles and typographical resources that lead to the determination of the journalistic genres, a matter that I intend to deal with in a future paper.

\section{NOTES}

1 According to the same author, the editor organizes and puts in order the news he has available, selects and reviews the material that is received, gives the lot to the workshops and has to answer politically and legally for the contents of the newspaper. His task consists in ordering and forming, considering that his merit is not so much in writing as in knowing how to seek what is newsworthy and in taking the initiative.

2 The development of this Outlook is based on various texts: Charles W. Morris, 1938: Foundations of the Theory of Signs, Univ. of Chicago (Spanish Edition: Fundamento de la teoría de los signos, Barcelona, 1985) and 1946: Signs, Language and Behavior, New York, 1946 (Spanish edition: Signos, lenguaje y conducta, Buenos Aires, 1962) and besides, Georges Mounin, 1972: Introducción a la semiología, (Introduction to Semiology), Barcelona; Decio Pignatari, 1977: Información, lenguaje, comunicación (Information, Language, Communication), Barcelona, and Eugenio de ustos, 1977: "Semantica, Semiología y Semiótica" (Semantics, Semiology and Semiotics), in Comunicación y lenguaje (Coord. Rafael Lapesa), Madrid.

3 Charles W. Morris presented this classification for the first time in 1938 in Fundaments of the Theory of Signs.

4 The conviction that the communication act is never totally aseptic is present in most texts published by information and communication sociologists. Since Harold D. Lasswell in 1948 established as a model the formula Who says what, in which channel, to whom, with what effects, numerous authors have studied this matter both in the United 
States (Jacques Bourquin, Joseph T. Klapper, Brude Smith, Ralph D. Casey, Wilbur Schramm, Donald F. Robers) as well as in Europe, where Francesco Fattorello insisted on the implicit subjectivity that existed in the person behind the message, and where the works of Miguel de Moragas and Angel Benito must be mentioned. Concerning the political weight of journalism and its influence on democratic practice, José María Deantes is one of the first who referred to informers as controllers of the res publica.

5 This classification attempts to establish a difference between communication that is solely knowledgeable and that which has an affective characteristic because it expresses values and emotions, and the communication of expressions or aesthetics. Knowledgeable, reflective or semantic contents are typical of information (cfr. SANABRIA, .25-29).

6 Chat: a conversation between various persons via the Internet.

7 The first division is that of Francesco Fattorello, and the second that of Emil Dovifat.

8 At this point we must again refer to digital media because periodicity, that was minimal in the case of the radio and on specific occasions, of television, became in cyberspace instantaneous for any type of information.

9 Journalism has as its specific purpose the objective diffusion of events through information, interpretation and comments on the events that are news (ALBERTOS, 1991: 41).

10 When we refer to publicity, its purpose is of a commercial type in a competitive market.

11 The diffusion of ideas or doctrines by means of emotive suggestion that tries to convince is propaganda.

12 Through public relations, a favorable climate on the part of the public towards an activity or service is sought.

13 Besides the definition given by the Dictionary of the Royal Spanish Academy, there are others such as those in the books quoted in footnote 2. Martinez de Sousa, after referring to Journalistic Newswriting as the peculiar form or Newswriting of journalists, says that it is a subject that forms part of studies on information, whose objective is to analyze the form and the contents of the message. Lopez de Zuazo expresses the 
same line of thought and adds that it is parallel to Linguistics and the General Theory of Information, but independent of them.

14 Cfr. P. Gaillard, 1972. This author proposes for the journalist culture, knowledge and the critical spirit of a historian, to which must be added fast judgment, in order to narrate only what interests his public.

\section{BIBLIOGRAPHY}

CASASÚS, Josep María. Iniciación a la Periodística. Barcelona: Teide, 1988.

COSTA, Pedro O. "Hipótesis para una metodología de la comunicación, in Comunicación y condición humana". I National Congress on Human Communication and Ecology, . 1972.

DEBBUS, Everette E. and ISMACH, Arnold H. Reporting Processes and Practices: Newswriting for Today's Readers. Belmont: Wadsworth Publishing Co., 1981.

DIEZHANDINO NIETO, María Pilar. El quehacer informativo. Bilbao: Universidad del Pais Vasco, 1994.

D’ORS, Alvaro. Sistema de las ciencias. Pamplona: EUNSA, 1969.

DOFIVAT, Emil. Periodismo. México: UTEHA, 1960.

EDO, Concepción. Del papel a la pantalla. La prensa en Internet. Seville: Comunicación Social, 2002.

ECO, Humberto. "Para una indagación semiológica sobre el mensaje televisivo" in Los efectos de la comunicación de masas. Buenos Aires. 1969.

FATTORELLO, Francesco. Introduzione alla tecnica sociale del Información. Rome (30 edition), 1964.

GAILLARD, Philippe. Técnica del periodismo. Barcelona: Oikodstau, 1972.

GITLIN, Todd. Enfermos de información. Barcelona: Paidós, 2005.

LOPEZ DE ZUAZO, Antonio. Diccionario del Periodismo. Madrid: Pirámide, 1976.

MARTINEZ ALBERTOS, José Luis. Curso General de Redacción Periodística. Madrid: Paraninfo, 1991.

MARTINEZ DE SOUSA, José. Diccionario General de Periodismo. Madrid: Paraninfo, 1992.

MORRIS, Charles W. Fundamentos de la teoría de los signos. Barcelona: Paidós, 1965. 
NUÑEZ LADEVEZE, Luis. Manual para periodismo. Barcelona: Ariel, 1965. 1979. El lenguaje de los "media". Madrid: Pirámide,

PISCITELLI, Alejandro. Internet, la imprenta del siglo XXI. Barcelona: Gedisa, 2005.

REAL ACADEMIA ESPAÑOLA. Diccionario de la lengua Española . Madrid: 21 st edition, volume II, 1992.

VIDAL BENEYTO, J. Las ciencias de la comunicación en la Universidad española. Bilbao, 1972.

Concepción Edo is Professor of the Science of Information Faculty at the Complutense University, Madrid. She has published three books - Periodismo informativo e interpretativo. El Impacto de Internet en la noticia, las fuentes y los géneros; Del papel a la pantalla. La Prensa en Internet; La crisis de la prensa diaria. Línea editorial y trayectoria de los diarios de Madrid - eighteen chapters in books of various authors, almost thirty articles published in scientific journals, and more than twenty speeches in expositions and participation in national and international congresses.

E-mail: edo.con@terra.es 